4 Columbia Business School
Center on Japanese Economy and Business

CENTER ON JAPANESE ECONOMYAND BUSINESS

日本经汶经営研究所

Working Paper Series

July 2013, No. 326

\title{
Good Jobs, Bad Jobs, and the Great Recession: Lessons from Japan's Lost Decade
}

Ryo Kambayashi and Takao Kato 


\title{
Good jobs, Bad jobs, and the Great Recession: Lessons from Japan's Lost Decade*
}

\author{
Ryo Kambayashi and Takao Kato**
}

CJEB Working Paper, July 21, 2013

\begin{abstract}
This paper provides novel evidence on the long-term effect of the Great Recession on the quality of jobs, in particular whether the Great Recession results in the replacement of "good jobs" (characterized by high wage/benefit, job security, and opportunity for training and development) with "bad jobs" (characterized by the lack of such attributes). Unfortunately there is not yet sufficiently long data from the recent Great Recession that enable researchers to study fully its long-term consequences for the labor market structure. To this end, we examine Japan's Lost Decade, the original Great Recession that occurred two decades ago. First, we find no evidence for a shift of male employment toward "bad jobs" during the Lost Decade. Second, for women we find a compositional change from self-employment to nonstandard employment which is, however, found to be a shift from "bad jobs" to "bad jobs" rather than "good jobs" to "bad jobs". As such, our findings cast doubt on the popular narrative of the long-term negative effect on job quality of the Great Recession. However, for one particular group of Japanese workers-youth, we find compelling evidence in support of the popular narrative. Especially all progresses that young women made in enhancing their share of standard employment during Japan's high growth decade in the 1980s are found to be entirely undone during the Lost Decade. The Great Recession affects the quantity of jobs and policy makers ought to pay immediate attention to such quantity effects. However, the Great Recession may also have more long-term structural effects on the quality of jobs, and such long-term effects may be heterogeneous, concentrating on a specific group of workers such as youth.
\end{abstract}

(JEL: J63, J64, J41)

Key words: job quality, good jobs and bad jobs, the Great Recession, Lost Decade, Japan

*This research was facilitated by Kato's extended visit to Hitotsubashi University as Visiting Scholar and Kambayashi's extended visit to the OECD as Consultant in OECD Employment Analysis and Policy Division. We are grateful for their hospitality. The opinions expressed and arguments employed here are the responsibility of the author(s) and do not necessarily reflect those of the OECD. This paper draws on Kambayashi (2010) which was supported by KoseiRodo Kakenhi (H20-policy-young-017). Kambayashi, Ryo."Jyoyo Hi-seiki Rodosha no Shosoh (Several Aspects on Non-regular Employees in Recent Japan)," Global COE Hi-Stat Discussion Paper Series 120. March 2010. (In Japanese).

**Kato is W.S. Schupf Professor of Economics and Far Eastern Studies, Colgate University; Research Fellow, IZA Bonn; and Research Associate, Center on Japanese Economy and Business (Columbia Business School), Tokyo Center for Economic Research (University of Tokyo), and Center for Corporate Performance (Aarhus School of Business). Ryo Kambayashi is Associate Professor, Institute of Economic Research, Hitotsubashi University. Kato is the corresponding author: Email; tkato@colgate.edu. Address: Department of Economics (Persson 222),Colgate University, 13 Oak Drive, Hamilton, NY 13346. Phone: 315-228-7562 Fax: 315-228-7033 


\section{Introduction}

One of the most pressing issues facing the U.S. and many other advanced market economies is to assess the long-term effects on their labor markets of the financial meltdown in the fall of 2008 and the subsequent Great Recession. ${ }^{1}$ To respond to the urgent need to inform policy makers on such an important issue, researchers have been undertaking various research projects. Reflecting the persistence of high unemployment rates in the U.S. and most other major advanced market economies, much of such recent research naturally focuses on job loss and long-term unemployment (see for example Farber, 2011; 2012, David and von Wachter, 2011; and Schmieder, von Wachter, and Bender, 2012).

Thus far researchers have not paid as much attention to long-term structural effects on the labor market of the Great Recession. For instance, it will be of great relevance and interest to policy makers to find out whether the Great Recession resulted in a significant change in the nature and quality of jobs as opposed to the quantity of jobs. More specifically we address the question of whether the Great Recession results in the replacement of "good jobs” (characterized by high wage/benefit, job security, control over own work, and opportunity for training and development) with “bad jobs” (characterized by low wage, weak job security, lack of control over own work, and limited opportunity for training and development) or vice versa (see Kalleberg, Reskin, and Hudson, 2000 and Kalleberg, 2011 for the recent good job/bad job framework). ${ }^{2,3}$

\footnotetext{
${ }^{1}$ Though the Great Recession in the U.S. officially ended in 2009, we refer to the ongoing economic stagnation with persistent high unemployment rates as the Great Recession in this paper.

${ }^{2}$ Acemoglu (2001) provides a theoretical model of the determination of the composition of "good jobs" and "bad job" in the economy.

${ }^{3}$ Recently the creation of "good jobs" and "bad job” during the Great Recession has become a hot political issue. Governor Perry buttressed his presidential candidacy by often citing his strong job creation record in the state of Texas during the Great Recession, while his opponents argue that the bulk of jobs created in Texas during the Great Recession are "bad job".
} 
Since structural changes such as the replacement of "good jobs" with "bad jobs” tend to occur gradually over many years, it is somewhat premature to study fully the long-term consequences of the Great Recession for the labor market structure. After all, it has been only a few years since the Great Recession began.

Fortunately, there was another Great Recession across the Pacific two decades ago. At the end of 1980s, the financial and real estate bubble were burst rather violently in Japan, which set the country into a prolonged economic stagnation, or the "Lost Decade". Notwithstanding some important differences between Japan's lost decade and the Great Recession, there are some intriguing similarities (Koo, 2008). A number of serious attempts have been made to contrast the Great Recession to Japan's “Lost Decade” in the 1990s, in search for historical lessons with regard to the causes and consequences of such severe and prolonged recession as well as appropriate policy responses (see, for instance, Hamada, Kashyap, and Weinstein, 2011 and Hoshi and Kashyap, 2010).

This paper provides the first rigorous evidence on changes in job quality (or lack thereof) during Japan's Great Recession which began in early 1990s and lasted for a decade. Specifically in the ensuing section we provide background information on the structure of the Japanese labor market and describe "good job" and "bad jobs" in the Japanese context. We then discuss two commonly used methods to identify the "good job" and "bad job" segments of the labor market in Japan, and assess the validity of each method econometrically. In sections 4-6 we document changes in the composition of employment (“good jobs” vs. "bad jobs”) during Japan’s Great Recession, followed by the concluding section.

\section{2. "Good jobs" and "Bad jobs" in Japan}


One of the most important changes in the workplace across the world in the last three decades is the rising prominence of a new work system often called the High Performance Work System or the High Involvement Work System. In short, in the High Performance Work System, first workers work in team, and produce product as well as engaging in problem solving activities and producing valuable local knowledge through their collective efforts and share it with management. Workers also deal with local shocks often autonomously through collaboration among themselves. Second, to sustain the interest and desire of workers to take full advantage of such problem solving activities on top of their regular production activities, the firm often pays efficiency wage (high wage/benefits). Furthermore, the interest alignment between workers and the firm is fostered by (i) financial participation schemes by which the financial wellbeing of workers is more tied to the final wellbeing of the firm; and (ii) information sharing mechanisms through which management shares important information with workers, and fosters their loyalty and commitment to the firm. Third, in the High Performance Work System workers are often provided with strong job security which will enable them to take advantage of the aforementioned opportunities wholeheartedly without fearing any job loss. Finally, careful screening and training are integral part of the High Performance Work System (see, for instance, Ichniowski, Shaw and Prennushi, 1997).

The High Performance Work System emerged first in Japan in the 1960s and diffused widely among Japanese firms in the late 1960s and the 1970s. Many firms in the West (in particular U.S. manufacturing firms) started to experiment with a similar system as part of their effort to match the Japanese challenge in the global market (see, for instance, Kato and Morishima, 2002 and Ichniowski and Shaw, 2003). ${ }^{4}$

\footnotetext{
${ }^{4}$ For more detailed analysis of the rise of the High Performance Work System in Japan, see Koike, 2005, Aoki, 2000, Itoh, 1994, Morita, 2001; 2005, Moriguchi and Ono, 2004 and Rebick, 2005).
} 
Nonetheless not all Japanese workers have been working under the High Performance Work System. There are a group of workers who constitute the secondary segment of the Japanese labor market, and work outside of the High Performance Work System. In fact, such secondary segment workers often function as a shock absorber in economic downturns by being the first to let go and thereby ensuring strong job security of the primary segment workers who work under the High Performance Work System. Such secondary segment workers are said to be paid lower wages, enjoy less generous benefit, less control over their work, weaker job security and more limited training opportunities than those primary segment workers (see for instance Koike, 2005 and Rebick, 2005).

In short, the primary segment workers (who work under the High Performance Work System) and the secondary segment workers (who tend to function as a shock absorber to ensure job security of the primary segment workers) fit well the descriptions of "good jobs" versus "bad jobs” workers in the recent good job/bad job framework (e.g., Kalleberg, 2011). One of the most commonly-held views on Japanese labor market responses to the Great Recession was that Japanese firms in response to the Great Recession increased their use of the secondary segment workers relative to the primary segment workers (Rebick, 2005, and Farber 2007a). In the framework of “good jobs” versus “bad jobs”, such a popular narrative suggests that Japan’s Great Recession might have shifted the composition of employment toward "bad jobs".

\section{Measuring the size of the good-job and bad-job sectors in Japan}

Measuring the size of the primary ("good job”) and secondary ("bad job”) segments of the Japanese labor market is an elusive enterprise (Ono, 2010). There are essentially two 
commonly-used methods to identify the primary and secondary segments of the Japanese labor market. The first method is based on the specific term of each worker's employment contract, and defines primary-segment workers as those on indefinite contracts and secondary -segment workers as those on fixed-term contracts. ${ }^{5}$

The second method is based on a custom in the place of each worker's actual employment. Specifically if a worker is termed "seishain (standard employee)" in the place of his/her employment, he/she is considered a primary-segment worker. Otherwise he/she is deemed a secondary-segment worker.

The first definition is based on the specific term (contract length) of each worker's legal employment contract, whereas the second definition is based on a custom/practice in the place of each worker's employment (or how the worker is actually termed in the place of his/her employment). To this end, we can interpret the first and second definitions as de jure and de facto definitions of the primary and secondary segments of the Japanese labor market.

It matters greatly which definition we use in studying the size of the secondary segment of the Japanese labor market. We draw Figure 1 using time-series data from the Labor Force Survey. First, the size of the secondary segment of the Japanese labor market as a percentage of total employment will be substantially greater when we use the de facto definition than when we use the de jure definition. Second and perhaps more importantly, the size of the secondary segment (measured by the de facto definition) as a percentage of total employment has been

${ }^{5}$ As discussed in Kambayashi and Kato (2011a), prior to its 1998 revision, Japan’s Labor Standards Law prohibited Japanese firms from offering multi-year fixed-term contracts. Hence all fixedyear contracts were one year or less. Since then Japanese firms have started to use multi-year contracts. To reflect this new regulatory environment, the Employment Status Survey (our primary data source for this paper's analysis) modified its de jure definition of the primary sector labor force and include such multi-year contracts (typically two to three years) workers, beginning with the 2007 ESS. As such, strictly speaking, starting with the most recent ESS (2007), employees on indefinite contracts include a small number of employees on multi-year contracts. 
rising steadily over the last twenty five years, whereas the size of the secondary segment (measured by the de jure definition) remained constant and only started to rise during Japan’s Lost Decade.

Furthermore, in principle, it is possible for a worker termed "standard employee" in the place of his/her employment to be legally on a fixed-term contract (standard employees on fixedterm contracts). Likewise, conceivably a worker on an indefinite contact is not termed "standard employee" in the place of his/her employment (nonstandard employees on indefinite contracts). As shown below, nonstandard employees on indefinite contracts have become increasingly popular over the years, and ultimately have outnumbered nonstandard employees on fixed-term contracts (often considered the most natural form of contingent work). ${ }^{6}$ The rising popularity of such hybrid types makes it important to take into consideration both definitions fully.

To further demonstrate the importance of paying particular attention to the definitional issue, we estimate the effects on worker outcomes of being a secondary-segment worker de jure (legally on fixed-term contracts) and de facto (not called standard employees in the place of employment).

We begin with a probit model of job loss rate and test whether being termed a standard employee in the workplace or being legally on an indefinite contract is more strongly associated with job security. ${ }^{7}$ Specifically we use the Employment Status Survey (ESS) for the most recent year (2007), and create a dummy variable, jobloss=1 if an employee lost a job as a result of the employer's decision unrelated to his/her individual performance (such as downsizing and

${ }^{6}$ The relevant literature is relatively small yet rich in content (e.g., Houseman and Osawa, 2003, Ozeki and Wakisaka, 2006, Honda, 2006, Esteban-Pretel, Nakajima, and Tanaka, 2011, Asano, Ito and Kawaguchi, 2011). However, on our reading of the literature, no prior study examines those hybrid groups and uncovers the relative importance of holding the title of "seiki no jyuugyouin" and being on indefinite contracts.

${ }^{7}$ Farber (2009) estimates a similar probit model for the U.S., and we apply a similar specification to our Japanese job loss data. 
"recommended" early retirement; bankruptcy and plant closing; and poor business performance) during the previous year, 0 otherwise. ${ }^{8}$ The Employment Status Survey (ESS) is the Japanese counterpart of CPS tenure supplements of the U.S. ${ }^{9}$ Due to the prevailing practice of mandatory retirement in Japan which was originally set at 55 (and then raised to 60 in the 1990s and 65 in the 2000s), we focus on age 18 to 54 .

Table 1 presents summary statistics where fixedterm=1 if an employee was on a fixedterm contract (as opposed to an indefinite contract) in the previous year, zero otherwise; nonstandard=1 if an employee was not termed a standard employee in the previous year, zero otherwise; female $=1$ if an employee is female, zero otherwise; age=years of age; ten0to $4=1$ if an employee's tenure with the firm was less than 5 years in the previous year, zero otherwise; ten5to9=1 if an employee's tenure with the firm was between 5 and 9 years in the previous year, zero otherwise; ten10to14=1 if an employee's tenure with the firm was between 10 and 14 years in the previous year, zero otherwise; and ten $15^{+=}=1$ if an employee's tenure with the firm was greater than 14 years in the previous year, zero otherwise; juniorhigh=1 if an employee's highest educational attainment was junior high school in the previous year, zero otherwise; highschool=1 if an employee's highest educational attainment was high school in the previous year, zero otherwise; juniorcollege=1 if an employee’s highest educational attainment was 2-year junior college in the previous year, zero otherwise; university=1 if an employee's highest educational attainment was 4-year university in the previous year, zero otherwise. Note that in creating these variables for employees who lost jobs, we use information on their previous jobs from which they separated.

\footnotetext{
${ }^{8}$ We focus on employees in this section, and hence self-employed individuals are excluded from the data. Our key results change little even if we include self-employed individuals as shown in section 5.

${ }^{9}$ One major difference between the ESS and CPS is its size. The ESS contains almost nine times more households than CPS.
} 
As shown in the table, the average annual job loss rate for Japanese employees age 18-54 was 3.7 percent in 2007. The proportion of employees on fixed-term contracts was around 7 percent, while the proportion of nonstandard employees was over 20 percent. Around 40 percent were female. The average age was 38, and the majority of them were high school graduates. ${ }^{10}$ Table 2 presents the probit estimates of job loss probability as a function of the aforementioned variables as well as other control variables (firm size, industry, occupation and location). Nearly all coefficients are estimated precisely. Most importantly the estimated coefficients on fixedterm and nonstandard are positive and statistically significant at the 1 percent level, confirming that employees on fixed-term contracts and nonstandard employees are indeed more likely to lose jobs and therefore enjoy less job security. The marginal effect estimates for fixedterm and nonstandard suggest that being not termed a standard employee in the workplace is substantially more detrimental for job security than being on a fixed-term contract.

As expected, employees with longer tenure are found to be less likely to lose jobs; and more educated employees are found to be less likely to lose jobs. The estimated coefficient on age and its marginal effect are positive and significant at the 1 percent level, suggesting that once tenure is controlled for, older workers are more likely than younger workers to be mid-career hires, and thereby face weaker job security in Japan (Kambayashi and Kato, 2011b). The estimated coefficient on female and its marginal effect are negative and statistically significant at the 1 percent level. Once obtaining the status of standard employment and being on indefinite contracts, female employees are actually less likely to lose jobs than their male counterparts. We suspect that this may be due to sorting - those female employees who earned the status of

${ }^{10}$ Unfortunately we are unable to use the ESS for earlier years, for the labor turnover module of the ESS for earlier years does not provide data on whether or not an employee was nonstandard employees during the previous year. 
standard employment on indefinite contracts in spite of various challenges associated with being female employees possess unusual gifts that are not fully accounted for by our set of control variables. At any rate, considering the rather small size of the estimated marginal effect of female, we may not want to overstate such sorting story.

To confirm that our key finding is not gender-specific, we repeat the same analysis for male and female employees separately. Tables 3 and 4 summarize the results for male and female employees. Reassuringly for both the male sample and the female sample the marginal effects on job loss rate of not holding the status of standard employment remain significant and considerably larger than the marginal effects on job loss rate of being on fixed-term contracts (in fact for female employees, the marginal effect of being on fixed-term contracts is no longer statistically significantly different from zero). As such, our main finding of the relative importance of holding the status of standard employment to being on indefinite contracts is upheld regardless of gender.

Next we estimate a standard Mincerian wage equation with log of hourly wage as a function of a variety of individual and firm characteristics, augmented by fixedterm and nonstandard (two variables to identify the secondary-segment workers). ${ }^{11}$ As in the case of job loss, we show the results for all employees first (Table 5) and then for male and female employees separately (Tables 6 and 7). Good news about the wage regressions is that unlike in the case of job loss, we need data only on current jobs and hence we will not need to rely on any data on previous jobs from the labor turnover module of the ESS for which information on the status of standard employment is not available for earlier years. As such we are able to estimate

${ }^{11}$ As in the case of many surveys of individuals in Japan, the ESS collects only categorical earnings data. We calculate hourly wage by dividing median of each category of annual earnings by annual working hours which we also derived from two additional categorical data on annual working days and weekly working hours. 
the wage equation for 2007 as well as for earlier years (1982, 1987, 1992, 1997, and 2002).

As shown in Table 5, the estimated coefficients on nonstandard are consistently negative and significant at the 1 percent level for each year over the last twenty five years. In contrast, the estimated coefficients on fixedterm are much smaller and mostly insignificant (when significant, they tend to have the wrong sign). The size of the wage penalty for not holding the status of standard employment has been considerable, rising from 16\% in 1982 to 26\% in 1997 and falling to $21 \%$ in 2007 . Note that the estimated wage penalty for nonstandard employment is conditional on age, age $^{2}$, tenure, tenure ${ }^{2}$, education, industry, occupation, firm size, and location as well as female. The estimated coefficients on female are negative and significant at the 1 percent level consistently for all years. The gender pay gap is sizable even after controlling for age, age ${ }^{2}$, tenure, tenure ${ }^{2}$, education, industry, occupation, firm size, location, as well as fixedterm and nonstandard. In 1982, it was almost 40 percent and has been falling steadily to almost 30 percent in 2007. Tables 6 and 7 again confirm that the relative importance of being termed standard employees in the workplace to being on indefinite contracts for wage is not gender-specific.

Finally, in 2007, the ESS began collecting data on the incidence of company-sponsored training and development. We use the 2007 ESS and estimate a probit model of the incidence of company-sponsored training and development program - probability that an employee participates in a company-sponsored training and development program as a function of fixedterm, nonstandard and other control variables. Tables 8-10 present the marginal effect estimates for the overall sample, the male sample, and the female sample respectively. As shown in the tables, again what really matters is whether or not an employee is called a standard employee in the place of employment not whether he/she is on an indefinite contract or on a fixed-term contract. This is true regardless of gender. Specifically the estimated marginal effect 
of nonstandard suggests that after controlling for the same set of control variables, being not a standard employee makes an employee a 7 percentage-point less likely to participate in a company-sponsored training and development program, which is not trivial considering that the likelihood of the average employee participating in such a training is about 42 percent.

In sum, we find consistent evidence that insofar as worker outcomes (job security, wage, and training and development opportunities) are concerned, being termed a standard employee in the workplace matters much more than being legally on an indefinite contract. Put differently, being a secondary-segment worker de facto is much more strongly associated with weaker job security, lower wage, and less training and development - "bad jobs" than being a secondarysegment worker de jure. ${ }^{12}$

\section{Did the composition of employment shift toward "bad jobs"?}

Guided by the conceptual framework discussed in the previous section, we divide the population aged 18-70 into the following groups: (i) standard employees on indefinite contracts (employees on the standard employment track and on indefinite contracts); (ii) nonstandard employees on fixed-term contracts (employees not on the standard employment track and on fixed-term contracts); (iii) standard employees on fixed-term contracts (employees on the standard employment track yet on fixed-term contracts); (iv) nonstandard employees on indefinite contracts (employees not on the standard employment track yet on indefinite contracts);

\footnotetext{
${ }^{12}$ We study job quality by focusing on the three main objective measures of worker outcomes-wage, job security, and training/development opportunity. The concept of job quality entails other domains such as autonomy. An alternative and equally valid approach would be to ask the workers to sum up all relevant domains of their jobs themselves and come up with their own overall job satisfaction scores. Unfortunately there is no reliable data on job satisfaction for a sufficiently large representative sample of Japanese workers that allow us to examine job satisfaction for different groups of workers such as standard employees on indefinite contracts; nonstandard employees on fixed contracts; other hybrids; and self-employed.
} 
(v) self-employed; and (vi) others (primarily those not in the labor force).

Much of the relevant literature ignores the self-employment segment when studying the relative size of the secondary segment of the Japanese labor market. Following the good job/bad job framework, we expand the scope of the analysis to include self-employment (Kalleberg, Reskin and Hudson, 2000). As shown below, the expanded scope of inquiry results in a rather surprising new finding concerning long-term trends in the relative size and importance of the secondary segment of the Japanese labor market.

From the ESS for 1982-2007 we calculate the proportion of each group for 1982, 1985, 1992, 1997, 2002, and 2007. Figure 2 shows such proportions including both male and female, while Figures 3 and 4 show them for male and female separately. First, overall the proportion of standard employees on indefinite contracts (who will be clearly identified as primary "good job" segment workers by either of the two definitions discussed in the previous section) displays rather remarkable stability over time. During Japan’s Great Recession, it did fall somewhat yet the magnitude of the fall was modest (42.7 percent in 1992 to 37.9 percent in 2002). To be consistent, the proportion of nonstandard employees on fixed-term contracts who will be unambiguously identified as secondary "bad job” segment workers by either definition also remained relatively stable throughout the period. During Japan’s Great Recession, there was a corresponding moderate increase in the proportion of such secondary segment workers from 6.1 to 8.1 percent.

The most noticeable shift, however, took place among self-employed and nonstandard employees on indefinite contracts. Self-employed workers as a percentage of the population aged 19-70 were over 20 percent in 1982 and since then they declined precipitously and reached below 12 percent by 2007. In contrast Figure 2 shows a remarkable increase in the proportion of 
nonstandard employees on indefinite contracts. In 1982 such a hybrid type was almost nonexistent yet by 2007 it reached the prominent status of 13 percent which actually exceeded the prevalence of self-employed. As shown in the previous section, being a secondary-segment worker de facto is far more strongly associated with weaker job security, lower wage, and less training and development - "bad jobs" than being a secondary-segment worker de jure. Thus, we determine that nonstandard employees on indefinite contracts -- the rapidly rising hybrid type is much closer to "bad jobs".

When we disaggregate Figure 2 by gender, a sharper picture on the sources of the decline in the relative importance of the "good job" sector emerges. For the male population, as shown in Figure 3, astonishingly standard employees on indefinite contracts as a percentage of the population aged 18-70 did not fall at all (actually rose from 58.3 in 1992 to 58.9 percent in 2002) during Japan's Lost Decade. Insofar as male workers are concerned, evidence does not support the popular narrative of significant shift of the Japanese labor force from the primary to the secondary segment during Japan’s Great Recession. Note that the share of male standard employees on indefinite contracts subsequently fell during Japan's longest uninterrupted positive (though modest) growth in the postwar era and reached 53.4 percent in 2007 and that correspondingly the aforementioned hybrid (nonstandard employees on indefinite contracts) surged from 2.9 percent in 2002 to 7.2 percent in 2007.

Figure 4 (as contrasted to Figure 3) reveals some intriguing gender differences. During the decade preceding its Great Recession (the heyday of the “Japanese miracle”), Japanese women increased their entry into the primary segment steadily (the percentage of female standard employees on indefinite contracts rose from 23.8 in 1982 to 26.6 percent in 1992). However, during the Great Recession, they lost what they had gained and the proportion of 
female standard employees on indefinite contracts fell from 26.6 in 1992 to 22.1 in 2002. There was a corresponding increase in the proportion of the hybrid (nonstandard employees on indefinite contracts) from 8.6 to 13.9 percent.

Meanwhile, self-employment as a percentage of the female population has been diminishing steadily over the last twenty five years from close to 20 percent in 1982 down to 8 percent in 2007. Back in 1982 self-employment was the second most common mode of work for women, and nonstandard employment with indefinite contracts was almost unheard of. By 2007, they traded places completely--nonstandard employment with indefinite contracts became the second most common mode of work for women after standard employment with indefinite contracts, whereas self-employment became one of the least common modes of work for women. As discussed before, the recent literature on contingent work in Japan often ignores the steadily diminishing importance of self-employment over the last twenty five years. An increase in nonstandard employment does not necessarily mean a decrease in standard employment. In the case of Japanese women, in 1992 (the beginning of Japan’s Lost Decade), nonstandard employment (including both indefinite and fixed-term contracts) constituted 17 percent of the total female population aged 18-70. By the end of the Lost Decade, nonstandard employment as a percentage of the total female population rose to almost 25 percent. In other words, during Japan's Lost Decade, nonstandard employment rose by 8 percentage points. However, it does not mean that standard employment as a percentage of the total population fell by 8 percentage points. It actually declined only by 4.5 percentage points. Much of the discrepancy was due to a considerable fall in self-employment.

5. Is substitution of nonstandard employment for self-employment a shift toward "bad jobs"? 
As shown in the previous section, a shift from standard employment to nonstandard employment can be legitimately considered a shift from "good jobs” to "bad jobs”. However, a shift from self-employment to nonstandard employment does not necessarily mean a shift from "good jobs" to "bad jobs", and it may well be a movement from "bad jobs” to "bad jobs", as stipulated in the good job/bad job framework (Kalleberg, Reskin and Hudson, 2000).

To shed light on the nature of the aforementioned shift of the female population from self-employment to nonstandard employment, we use all female workers including selfemployed and estimate a Mincerian earnings equation. The dependent variable is log of hourly earnings and our key independent variables are a set of four dummy variables: (i) "nonstandard and fixed" which takes a value of one if the female worker is a nonstandard employee on a fixed contract, zero otherwise; (ii) "nonstandard and indefinite" which takes a value of one if the female worker is a nonstandard employee on an indefinite contract, zero otherwise; (iii) "standard and fixed" which takes a value of one if the female worker is a standard employee on a fixed contract, zero otherwise; and (iv) "self-employed" which takes a value of one if the female worker is self-employed, zero otherwise (the omitted reference is "standard and indefinite" which takes a value of one if the female worker is a standard employee on an indefinite contract, zero otherwise). As in the case of the previous section, we control for age, age ${ }^{2}$, tenure, tenure ${ }^{2}$, education, industry, occupation, firm size, and location.

The results are summarized in Table 11. The estimated coefficients on the employment status dummy variables are all statistically significant at the 1 percent level. The estimated coefficients on "selfemployed" and "nonstandard and indefinite" suggest that for all years except for 1992 self-employed women on average earns (per hour) significantly less than women who are nonstandard employees on indefinite contracts, after controlling for a variety of individual and firm characteristics. ${ }^{13}$ For instance, in

\footnotetext{
${ }^{13}$ The estimated coefficients on self-employed are found to be statistically significantly different
} 
2007, self-employed women earned over 40 percent less than female standard employees on indefinite contracts, while female nonstandard employees on indefinite contracts earned about 20 percent less than female standard employees on indefinite contracts. As such, in 2007, substitution of nonstandard employment on indefinite contracts for self-employment represented a rise (rather than a fall) of hourly earnings.

However, hourly earnings may not be entirely comparable between self-employed and employed women. As such, the above conclusion ought not to be considered definitive. Nonetheless, our analysis at least suggests that the compositional shift from self-employment to nonstandard employment among Japanese women over the last twenty five years may not be a shift from good jobs to bad jobs, rather a change from one type of bad jobs to another type of bad jobs. ${ }^{14}$

Finally, we explore to what extent the aforementioned compositional shift from self-employment to nonstandard employment on indefinite contracts among Japanese women results from the direct transition of the same women from self-employment to nonstandard employment on indefinite contracts. To shed light on this, we pool all years of the ESS and create an annual transition matrix (Table 12). As shown in the table, the most common destination for women who transition from self-employment is nonemployment. More importantly the direct transition of the same women from self-employment to nonstandard employment on indefinite contracts is rare (Since employees on indefinite contracts include both standard and nonstandard employees on indefinite contracts, the fraction of self-employed job changers who transitioned to nonstandard employees on indefinite contracts are even smaller). ${ }^{15}$ The aforementioned compositional shift from self-employment to nonstandard employment on indefinite contract does not seem to be a result of the direct transitions of the same women from self-employment to

from those on nonstandard and indefinite.

${ }^{14}$ We also ran similar regressions, using hours worked instead of log of hourly earnings as the dependent variable. Conditional on a variety of individual and firm characteristics, nonstandard employees on indefinite contracts are found to work significantly fewer hours than standard employees on indefinite contracts, whereas self-employed women are found to work as many hours as standard employees on indefinite contracts.

${ }^{15}$ The ESS does not allow us to separate job changers who transitioned to nonstandard employees on indefinite contracts from job changers who transitioned to standard employees on indefinite contracts. 
nonstandard employment. Rather it is more consistent with an intergenerational transition--aging women working for their small family businesses (such as selling rice balls, candies, and soft drinks at their corner stores) retire (and hence transition to non-employment), while a growing number of younger women enter the labor market as nonstandard employees on indefinite contracts, as shown in the next section.

It is beyond the scope of this paper to identify the underlying causes of the compositional shift of female employment from self-employment to nonstandard employment on indefinite contracts. We speculate that the replacement of small family businesses with large corporations may be the underlying cause of the observed compositional change in female employment from self-employment to nonstandard employment on indefinite contracts. For instance, it is plausible that large retail chains (e.g., Seven Elevens) have been replacing small mom and pop stores, and that aging women working for such family businesses as self-employed workers retire and close their mom and pop stores, while their daughters work for large retail chains as nonstandard employees. ${ }^{16}$ To shed light on this, we calculate the change in the proportion of nonstandard employees on indefinite contracts from 1982 to 2002 and the change in the proportion of self-employment over the same time period for different industries, and plot them in Figure 5. The scatter diagram points to a negative correlation between the change in the proportion of nonstandard employees on indefinite contracts from 1982 to 2002 and the change in the proportion of self-employment over the same time period. As such, those industries with large reductions in the proportion of self-employment over the 20 years period appear to be also those with large increases in the proportion of nonstandard employment with indefinite contracts. In other words, the compositional change of female employment from selfemployment to nonstandard employment may well be taking place largely within the industry. Such within-industry changes are consistent with our speculation that the changing market structure of some industries from mom and pop stores to large oligopolists may be behind the

\footnotetext{
${ }^{16}$ A similar story was presented and documented by Haltiwanger, Jarmin, and Krizan (2010).
} 
observed shift of women from self-employment to nonstandard employment.

\section{What about youth?}

Finally, another popular narrative with regard to the victims of Japan’s Lost Decade concerns youth (see, for instance, Genda, 2003). To this end, we repeat the same analysis, limiting the sample to the relevant youth population aged 22-30. Figures 6-8 summarize the results. Overall, we find evidence in favor of this popular narrative. As shown in Figure 5, among youth, there was a ten-percentage point drop in standard employees on indefinite contracts as a percentage of the population during the Great Recession (63.5 in 1992 to 53.8 percent in 2002). There was a corresponding rise in nonstandard employees on indefinite contracts as well as nonstandard employees on fixed-term contract. Japan’s Lost Decade was indeed accompanied by a shift of the composition of youth employment toward "bad jobs."

An intriguing historical gender difference is revealed in Figures 6 and 7. Among male youth, the proportion of standard employees on indefinite contracts remained quite high around 76-77 percent during Japan's growth decade preceding the Lost Decade. During the Lost Decade, however, it declined by about 10 percentage points, and during the post-Lost Decade recovery period, there was no recovery in the proportion of standard employees on indefinite contracts. In contrast, during Japan’s growth decade of 1982-1992, young women in Japan had a significant stride toward "good jobs" - standard employees on indefinite contracts as a percentage of the relevant population rose by about ten percentage points from below 40 percent in 1982 to close to 50 percent in 1992. It appears as if nearly all of such gains were lost during Japan's Lost Decade. Meanwhile, nonstandard employment (including both indefinite and fixed contract jobs) as a percentage of the population surged from 6.2 to 14.6 percent and from 6.4 to 10.7 percent 
respectively.

In sum, it is the case that for both genders the composition of youth employment shifted significantly toward “bad jobs” during Japan’s Great Recession. For young women in Japan, such a loss of “good jobs” during Japan’s Great Recession meant a complete undoing of progress they had made during the preceding decade.

\section{Concluding remarks: Summary, Interpretations, and Policy Implications}

This paper has provided novel evidence on the possible long-term effects of the Great Recession on the nature and quality of jobs as opposed to the quantity of jobs. More specifically we have addressed the question of whether the Great Recession results in the replacement of "good jobs” (characterized by high wage/benefit, job security, and opportunity for training and development) with "bad jobs” (characterized by the lack of such attributes). Since structural changes such as the replacement of "good jobs" with "bad jobs" tend to occur gradually over many years, it is somewhat premature to study fully the long-term consequences of the most recent Great Recession following the financial crisis in the fall of 2008 for the labor market structure. After all, it has been only several years since the Great Recession began, and there is not yet sufficiently long data that enable researchers to study their long-term effects. To this end, we have chosen to look across the Pacific and examine Japan's Lost Decade, the original Great Recession that occurred two decades ago.

The popular narrative about the labor market consequences of Japan's Lost Decade was that during the Lost Decade there was a significant shift of the composition of employment toward "bad jobs." Overall we have found no evidence for such a shift insofar as the total male population is concerned. However, the composition of female employment appeared to have 
shifted significantly toward "bad jobs", and such a shift occurred primarily through an increased use of a hybrid employment contract of nonstandard employment with indefinite (open-ended) contracts. Nonetheless, a closer look at the data (including self-employment) has revealed that the increasing use of the hybrid contracts (nonstandard employment on indefinite contracts) does not necessarily mean the decreasing use of standard employment contracts, and that the most notable compositional change in female employment turned out to be a shift of female employment from self-employment to nonstandard employment on indefinite contracts. Our regression analysis has yielded evidence suggesting that the compositional shift of female employment from self-employment to nonstandard employment on indefinite contracts is likely to be a shift from "bad jobs" to "bad jobs".

Overall, our analysis casts doubt on the popular narrative that during Japan's Lost Decade, Japanese employment shifted toward "bad jobs". However, insofar as youth is concerned, we have found evidence in favor of the popular narrative, indeed—youth employment shifted significantly toward “bad jobs” during Japan’s Great Recession. Particularly young women in Japan made considerable progress in shifting the composition of their employment toward "good jobs” during Japan’s growth decade preceding the Lost Decade. Unfortunately our evidence indicates that such progress was entirely undone during the Great Recession.

Let us conclude by discuss some policy lessons from Japan’s lost decade. During the Lost Decade, Japan’s unemployment rate never exceeded 5.4 percent. A quick comparison of OECD harmonized unemployment rates among major advanced economies over the last twenty five years gives us an impression that Japan weather her own Great Recession rather well in terms of the labor market outcomes. When we go beyond the quantity of jobs and start analyzing the quality of jobs, however, a more nuanced assessment of the labor market outcome during Japan's 
Great Recession emerges - heterogeneous labor market effects of the Great Recession.

For policy makers who are concerned about the long-term effect on the labor market of the recent financial crisis and ensuing global Great Recession, Japan’s Lost Decade offers a valuable lesson. Obviously the Great Recession affects the quantity of jobs and policy makers ought to pay immediate attention to such quantity effects. It is, however, quite plausible that the Great Recession may have more long-term structural effects on the nature and quality of jobs. Such quality effects may appear only after a long gestation period and can be difficult to detect. Nonetheless precisely because of their potentially profound consequences for the wellbeing of workers and the society, policy makers may need to be particularly cognizant of the long-term effects of the Great Recession on the structure of the labor market in general and any shifts of the composition of employment in particular. 
References

Acemoglu, Daron. "Good Jobs Versus Bad Jobs." Journal of Labor Economics, 2001, 19(1), pp. $1-21$.

Aoki, Masahiko. Information, Corporate Governance, and Institutional Diversity: Competitiveness in Japan, the USA, and the Transitional Economies. Oxford and New York: Oxford University Press, 2000.

Asano, Hirokatsu; Ito, Takahiro and Kawaguchi, Daiji. "Why Has the Fraction of Contingent Workers Increased? A Case Study of Japan," RIETI Discussion Paper Series 11-E-021, 2011.

Davis, Steven, J. and von Wachter, Till "Recessions and the Costs of Job Loss," the 2011 Fall conference of the Brookings Papers on Economic Activity. Brookings Institution, 2011.

Esteban-Pretel, Julen; Nakajima, Ryo and Tanaka, Ryuichi. "Are Contingent Jobs Dead Ends or Stepping Stones to Regular Jobs? Evidence from a Structural Estimation." Labour Economics, 2011, 18(4), pp. 513-26.

Farber, Henry. "Job Loss in the Great Recession: Historial Perspective from the Displaced Workers Survey, 1984-2010," NBER Working Paper No. 17040, 2011.

. "Labor Market Adjustment to Globalization: Long-Term Employment in the United States and Japan," Paper presented by the Trans Pacific Labor Seminar. Santa Barbara, CA, 2007b.

Farber, Henry S. "Unemployment in the Great Recession: Did the Housing Market Crisis Prevent the Unemployed from Moving to Take Jobs?" American Economic Review, 2012, 102(3), pp. 520-25.

Genda, Yuji. "Who Really Lost Jobs in Japan? Youth Employment in an Aging Japanese Society," S. Ogura, T. Tachibanaki and D. A. Wise, Labor Markets and Firm Benefit Policies in Japan and the United States. Chicago and London: University of Chicago Press, 2003, 103-33.

Haltiwanger, John; Jarmin, Ron and Krizan, C. J. "Mom-and-Pop Meet Big-Box: Complements or Substitutes?" Journal of Urban Economics, 2010, 67(1), pp. 116-34.

Hamada, Koichi; Kashyap, Anil and Weinstein, David eds. Japan's Bubble, Deflation, and Stagnation. Cambridge, MA: MIT Press, 2011.

Honda, Kazunari. "Employment Policies and Labor Union Activities for Part-Time Workers and Dispatched Workers in Japan," S. E. Gleason, The Shadow Workforce: Perspectives on Contingent Work in the United States, Japan, and Europe. Kalamazoo, Mich.: W. E. Upjohn Institute for Employment Research, 2006, 241-67.

Hoshi, Takeo and Kashyap, Anil K. "Will the U.S. Bank Recapitalization Succeed? Eight Lessons from Japan." Journal of Financial Economics, 2010, 97(3), pp. 398-417.

Houseman, Susan and Osawa, Machiko. "The Growth of Nonstandard Employment in Japan and the United States," S. Houseman and M. Osawa, Nonstandard Work in Developed Economies: Causes and Consequences. Kalamazoo, Mich.: W. E. Upjohn Institute for Employment Research, 2003, 175-214.

Ichniowski, Casey and Shaw, Kathryn. "Beyond Incentive Pay: Insiders' Estimates of the Value of Complementary Human Resource Management Practices." Journal of Economic Perspectives, 2003, 17(1), pp. 155-80.

Ichniowski, Casey; Shaw, Kathryn and Prennushi, Giovanna. "The Effects of Human Resource Management Practices on Productivity: A Study of Steel Finishing Lines." 
American Economic Review, 1997, 87(3), pp. 291-313.

Itoh, Hideshi. "Japanese Human Resource Management from the Viewpoint of Incentive Theory," M. Aoki and R. Dore, The Japanese Firm: The Sources of Competitive Strength. Oxford and New York: Oxford University Press, 1994, 233-64.

Kalleberg, Arne L. . Good Jobs, Bad Jobs: The Rise of Polarized and Precarious Employment Systems in the United States, 1970s to 2000s. New York: Russell Sage, 2012.

Kalleberg, Arne L.; Reskin, Barbara F. and Hudson, Ken. "Bad Jobs in America: Standard and Nonstandard Employment Relations and Job Quality in the United States." American Sociological Review, 2000, 65, pp. 256-78.

Kambayashi, Ryo and Kato, Takao. "The Japanese Employment System after the Bubble Burst: New Evidence," K. Hamada, A. Kashyap and D. Weinstein, Japan’s Bubble, Deflation, and Stagnation Cambridge, MA: MIT Press, 2011a, 217-62.

. "Long-Term Employment and Job Security over the Last Twenty-Five Years: A Comparative Study of Japan and the U.S.," IZA discussion paper 6183, $2011 \mathrm{~b}$.

Kato, Takao. "The Recent Transformation of Participatory Employment Practices," S. Ogura, T. Tachibanaki and D. Wise, Nber Conference Report Labor Markets and Firm Benefit Policies in Japan and the United States. Chicago: University of Chicago Press, 2003, 3980.

Kato, Takao and Morishima, Motohiro. "The Productivity Effects of Participatory Employment Practices: Evidence from New Japanese Panel Data." Industrial Relations, 2002, 41(4), pp. 487-520.

Koike, Kazuo. Shigoto No Keizaigaku (Economics of Work). Tokyo: Toyo Keizai, 2005.

Koo, Richard. The Holy Grail of Macroeconomics: Lessons from Japan's Great Recession. Wiley, 2009.

Moriguchi, Chiaki and Ono, Hiroshi. "Japanese Lifetime Employment: A Century's Perspective," EIJS Working Paper Series No. 205, 2004.

Morita, Hodaka. "Choice of Technology and Labour Market Consequences: An Explanation of U.S.-Japanese Differences." Economic Journal, 2001, 111(468), pp. 29-50.

- "Multi-Skilling, Delegation and Continuous Process Improvement: A Comparative Analysis of Us-Japanese Work Organizations." Economica, 2005, 72(285), pp. 69-93.

Ono, Hiroshi. "Lifetime Employment in Japan: Concepts and Measurements." Journal of the Japanese and International Economies, 2010, 24(1), pp. 1-27.

Ozeki, Cynthia and Wakisaka, Akira. "Japan's Growing Shadow Workforce," S. E. Gleason, The Shadow Workforce: Perspectives on Contingent Work in the United States, Japan, and Europe. Kalamazoo, Mich.: W. E. Upjohn Institute for Employment Research, 2006, 203-39.

Rebick, Marcus. The Japanese Employment System: Adapting to a New Economic Environment. Oxford and New York: Oxford University Press, 2005.

Schmieder, Johannes F.; von Wachter, Till and Bender, Stefan. "The Long-Term Effects of Ui Extensions on Employment." American Economic Review, 2012, 102(3), pp. 514-19.

Steinberg, Chad and Nakane, Masato. "To Fire or to Hoard? Explaining Japan’s Labor Market Response in the Great Recession," IMF Working Paper. IMF, 2011. 
Table 1 Summary Statistics for Probit Analysis of Job Loss in 2007

\begin{tabular}{ccc} 
& observation & mean \\
\hline jobloss & 151208 & 0.037 \\
fixedterm & 151208 & 0.071 \\
nonstandard & 151208 & 0.212 \\
female & 151208 & 0.393 \\
age & 151208 & 37.846 \\
age $^{2} / 100$ & 151208 & 15.358 \\
ten0to4 & 151208 & 0.284 \\
ten5to9 (base) & 151208 & 0.219 \\
ten10to14 & 151208 & 0.139 \\
ten15+ & 151208 & 0.358 \\
juniorhigh (base) & 151208 & 0.061 \\
highschool & 151208 & 0.621 \\
juniorcollege & 151208 & 0.091 \\
university & 151208 & 0.227 \\
\hline \hline
\end{tabular}

Source: the Employment Status Survey, 2007.

Note: The sample consists of all job holders aged 18 to 54 as of October, 2006. For variable definitions, please see the text. 
Table 2 Probit Estimates of the Determinants of Job Loss Probability in 2007: All employees Dependent Variable: Jobloss=1 if the employee lost a job during the previous year, 0 otherwise

\begin{tabular}{lcclccc} 
& Coeff. & s.e. & & M.E. & s.e. & \\
\hline fixedterm & 0.053 & 0.023 & $* *$ & 0.003 & 0.002 & $* *$ \\
nonstandard & 0.208 & 0.018 & $* * *$ & 0.014 & 0.001 & $* * *$ \\
female & -0.051 & 0.017 & $* * *$ & -0.003 & 0.001 & $* * *$ \\
age & 0.072 & 0.005 & $* * *$ & 0.004 & 0.000 & $* * *$ \\
age2 & -0.083 & 0.007 & $* * *$ & -0.005 & 0.000 & $* * *$ \\
ten0to4 & 0.309 & 0.017 & $* * *$ & 0.022 & 0.001 & $* * *$ \\
ten10to14 & -0.053 & 0.022 & $* *$ & -0.003 & 0.001 & $* *$ \\
ten15+ & -0.332 & 0.021 & $* * *$ & -0.019 & 0.001 & $* * *$ \\
highschool & -0.045 & 0.024 & $*$ & -0.003 & 0.002 & $*$ \\
juniorcollege & -0.044 & 0.032 & & -0.003 & 0.002 & \\
university & -0.120 & 0.030 & $* * *$ & -0.007 & 0.002 & $* * *$ \\
obs & \multicolumn{7}{c}{151208} \\
obs prob & \multicolumn{7}{c}{0.037} & & &
\end{tabular}

Notes: For variable definitions, please see the text. The omitted tenure category is 5-9 years of tenure (ten5to9). The omitted educational attainment category is junior high school or less. Firm size, industry, occupation and location are also controlled for.

***significant at the 1 percent level; **significant at the 5 percent level; *significant at the 10 percent level. 
Table 3 Probit Estimates of the Determinants of Job Loss Probability in 2007: Male employees Dependent Variable: Jobloss $=1$ if the employee lost a job during the previous year, 0 otherwise

\begin{tabular}{lcclccc} 
& Coeff. & s.e. & & M.E. & s.e. & \\
\hline fixedterm & 0.122 & 0.042 & $* * *$ & 0.007 & 0.003 & $* * *$ \\
nonstandard & 0.218 & 0.031 & $* * *$ & 0.013 & 0.002 & $* * *$ \\
age & 0.077 & 0.008 & $* * *$ & 0.004 & 0.000 & $* * *$ \\
age2 & -0.083 & 0.010 & $* * *$ & -0.004 & 0.001 & $* * *$ \\
ten0to4 & 0.314 & 0.024 & $* * *$ & 0.019 & 0.002 & $* * *$ \\
ten10to14 & -0.114 & 0.031 & $* *$ & -0.005 & 0.001 & $* *$ \\
ten15+ & -0.426 & 0.028 & $* * *$ & -0.021 & 0.001 & $* * *$ \\
highschool & -0.035 & 0.031 & & -0.002 & 0.002 & \\
juniorcollege & -0.044 & 0.057 & & -0.002 & 0.003 & \\
university & -0.107 & 0.037 & $* * *$ & -0.005 & 0.002 & $* * *$ \\
obs & & \multicolumn{7}{c}{91769} \\
obs prob & & \multicolumn{2}{c}{0.031} & &
\end{tabular}

Source: the Employment Status Survey, 2007.

Notes: For variable definitions, please see the text. The omitted tenure category is 5-9 years of tenure (ten5to9). The omitted educational attainment category is junior high school or less. Firm size, industry, occupation and location are also controlled for.

***significant at the 1 percent level; **significant at the 5 percent level; *significant at the 10 percent level. 
Table 4 Probit Estimates of the Determinants of Job Loss Probability in 2007: Female employees Dependent Variable: Jobloss $=1$ if the employee lost a job during the previous year, 0 otherwise

\begin{tabular}{lcccccc} 
& Coeff. & s.e. & & M.E. & s.e. & \\
\hline fixedterm & 0.033 & 0.027 & & 0.003 & 0.002 & \\
nonstandard & 0.223 & 0.023 & $* * *$ & 0.018 & 0.002 & $* * *$ \\
age & 0.072 & 0.008 & $* * *$ & 0.006 & 0.001 & $* * *$ \\
age2 & -0.090 & 0.010 & $* * *$ & -0.007 & 0.001 & $* * *$ \\
ten0to4 & 0.295 & 0.024 & $* * *$ & 0.025 & 0.002 & $* * *$ \\
ten10to14 & 0.029 & 0.033 & & 0.002 & 0.003 & \\
ten15+ & -0.195 & 0.034 & $* * *$ & -0.014 & 0.002 & $* * *$ \\
highschool & -0.035 & 0.040 & & -0.003 & 0.003 & \\
juniorcollege & -0.032 & 0.046 & & -0.002 & 0.003 & \\
university & -0.102 & 0.052 & $* *$ & -0.007 & 0.003 & $* *$ \\
obs & & \multicolumn{7}{c}{59439} & & &
\end{tabular}

Source: the Employment Status Survey, 2007.

Notes: For variable definitions, please see the text. The omitted tenure category is 5-9 years of tenure (ten5to9). The omitted educational attainment category is junior high school or less. Firm size, industry, occupation and location are also controlled for. ***significant at the 1 percent level; **significant at the 5 percent level; *significant at the 10 percent level. 
Table 5 OLS Estimates on the effects on log of hourly wage of being on fixed-term contracts and being not on the standard employment track over 1982-2007: all employees

\begin{tabular}{|c|c|c|c|c|c|c|}
\hline & (1) & (2) & (3) & (4) & (5) & (6) \\
\hline Year & 1982 & 1987 & 1992 & 1997 & 2002 & 2007 \\
\hline Dependent variable & \multicolumn{6}{|c|}{ ln (hourly wage) } \\
\hline fixedterm & $\begin{array}{c}-0.034^{* * *} \\
(0.004)\end{array}$ & $\begin{array}{c}0.004 \\
(0.004)\end{array}$ & $\begin{array}{c}0.000 \\
(0.004)\end{array}$ & $\begin{array}{c}0.015^{\text {*** }} \\
(0.003)\end{array}$ & $\begin{array}{c}0.001 \\
(0.003)\end{array}$ & $\begin{array}{c}0.018^{* * *} \\
(0.003)\end{array}$ \\
\hline nonstandard & $\begin{array}{c}-0.160^{* * *} \\
(0.004)\end{array}$ & $\begin{array}{c}-0.173^{* * *} \\
(0.003)\end{array}$ & $\begin{array}{c}-0.227^{* * *} \\
(0.003)\end{array}$ & $\begin{array}{c}-0.256^{* * *} \\
(0.003)\end{array}$ & $\begin{array}{c}-0.220^{* * *} \\
(0.003)\end{array}$ & $\begin{array}{c}-0.208^{* * * *} \\
(0.003)\end{array}$ \\
\hline female & $\begin{array}{c}-0.391^{* * * *} \\
(0.002)\end{array}$ & $\begin{array}{c}-0.365^{* * * *} \\
(0.002)\end{array}$ & $\begin{array}{c}-0.373^{* * * *} \\
(0.002)\end{array}$ & $\begin{array}{c}-0.351^{* * *} \\
(0.002)\end{array}$ & $\begin{array}{r}-0.331^{* * *} \\
(0.002)\end{array}$ & $\begin{array}{c}-0.292^{* * *} \\
(0.002)\end{array}$ \\
\hline Observations & 310930 & 312896 & 405155 & 393614 & 342259 & 346561 \\
\hline Adj. R-squared & 0.587 & 0.568 & 0.562 & 0.556 & 0.522 & 0.461 \\
\hline
\end{tabular}

Source: the Employment Status Survey, 1982, 1987, 1992, 1997, 2002, and 2007.

Notes: For variable definitions, please see the text. All regressions include the following controls: age, age ${ }^{2}$, tenure, tenure ${ }^{2}$, education, industry, occupation, firm size, and location. Standard errors in parentheses.

***significant at the 1 percent level; **significant at the 5 percent level; *significant at the 10 percent level. 
Table 6 OLS OLS Estimates on the effects on log of hourly wage of being on fixed-term contracts and being not on the standard employment track over 1982-2007: male employees

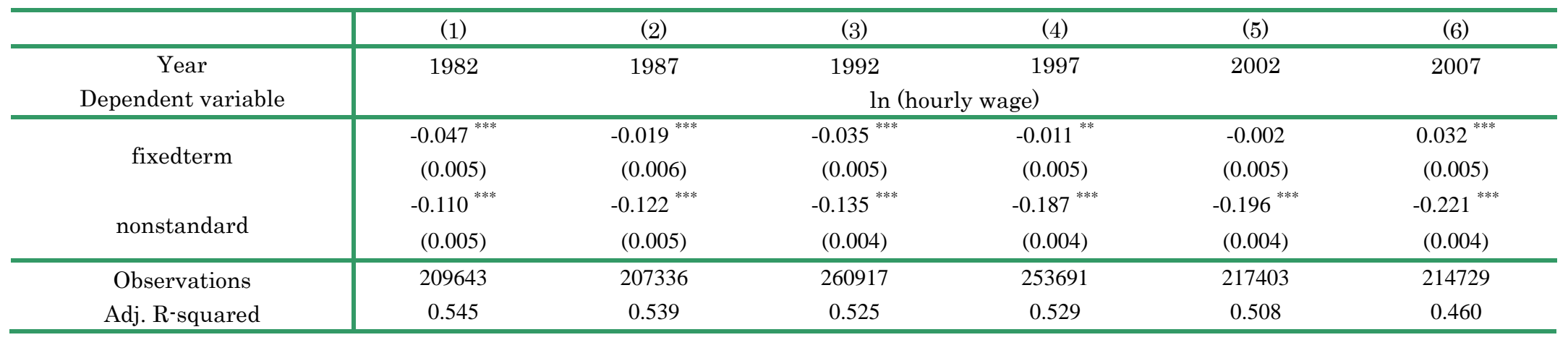

Source: the Employment Status Survey, 1982, 1987, 1992, 1997, 2002, and 2007.

Notes: For variable definitions, please see the text. All regressions include the following controls: age, age ${ }^{2}$, tenure, tenure ${ }^{2}$, education, industry, occupation, firm size, and location. Standard errors in parentheses.

***significant at the 1 percent level; **significant at the 5 percent level; *significant at the 10 percent level. 
Table 7. OLS Estimates on the effects on log of hourly wage of being on fixed-term contracts and being not on the standard employment track over 1982-2007: female employees

\begin{tabular}{|c|c|c|c|c|c|c|}
\hline & (1) & (2) & (3) & (4) & (5) & (6) \\
\hline Year & 1982 & 1987 & 1992 & 1997 & 2002 & 2007 \\
\hline Dependent variable & \multicolumn{6}{|c|}{$\ln$ (hourly wage) } \\
\hline fixedterm & $\begin{array}{c}-0.033^{* * *} \\
(0.006)\end{array}$ & $\begin{array}{l}-0.008 \\
(0.006)\end{array}$ & $\begin{array}{c}-0.015^{* * *} \\
(0.005)\end{array}$ & $\begin{array}{c}-0.009^{*} \\
(0.005)\end{array}$ & $\begin{array}{c}-0.020^{* * *} \\
(0.005)\end{array}$ & $\begin{array}{c}-0.012^{* *} \\
(0.005)\end{array}$ \\
\hline nonstandard & $\begin{array}{c}-0.160^{* * *} \\
(0.005)\end{array}$ & $\begin{array}{c}-0.151^{* * *} \\
(0.005)\end{array}$ & $\begin{array}{c}-0.228^{* * *} \\
(0.004)\end{array}$ & $\begin{array}{c}-0.243^{* * *} \\
(0.004)\end{array}$ & $\begin{array}{c}-0.213^{* * *} \\
(0.004)\end{array}$ & $\begin{array}{c}-0.185^{* * *} \\
(0.004)\end{array}$ \\
\hline Adj. R-squared & 0.432 & 0.421 & 0.427 & 0.434 & 0.412 & 0.351 \\
\hline
\end{tabular}

Source: the Employment Status Survey, 1982, 1987, 1992, 1997, 2002, and 2007.

Notes: For variable definitions, please see the text. All regressions include the following controls: age, age ${ }^{2}$, tenure, tenure ${ }^{2}$, education, industry, occupation, firm size, and location. Standard errors in parentheses.

***significant at the 1 percent level; **significant at the 5 percent level; *significant at the 10 percent level. 
Table 8 Probit Estimates on the marginal effects on the incidence of company-sponsored training of being on fixed-term contracts and being not on the standard employment track in 2007: All employees

\begin{tabular}{c|c}
\hline & \\
\hline Dependent variables & $\begin{array}{c}\text { Prob (participation in } \\
\text { company-sponsored training } \\
\text { and development program) }\end{array}$ \\
\hline fixedterm & 0.004 \\
nonstandard & $(0.004)$ \\
female & $-0.072^{* * *}$ \\
& $(0.003)$ \\
Observations & $-0.007^{* * *}$ \\
Pseudo R-squared & $(0.002)$ \\
Obs. Probability & 345238 \\
Predicted Probability & 0.139 \\
\hline
\end{tabular}

Source: the Employment Status Survey, 2007.

Notes: For variable definitions, please see the text. All regressions include the following controls: age, age ${ }^{2}$, tenure, tenure ${ }^{2}$, education, industry, occupation, firm size, location, hourly wage, annual hours worked, and intention to quit. Standard errors in parentheses.

***significant at the 1 percent level; **significant at the 5 percent level; *significant at the 10 percent level. 
Table 9 Probit Estimates on the marginal effects on the incidence of company-sponsored training of being on fixed-term contracts and being not on the standard employment track in 2007: male employees

\begin{tabular}{c|c}
\hline Dependent variables & $\begin{array}{c}\text { Prob (participation in } \\
\text { company-sponsored training } \\
\text { and development program) }\end{array}$ \\
\hline fixedterm & -0.003 \\
nonstandard & $(0.006)$ \\
\hline Observations & $-0.071^{* * *}$ \\
Pseudo R-squared & $(0.004)$ \\
Obs. Probability & 213936 \\
Predicted Probability & 0.116 \\
\hline
\end{tabular}

Source: the Employment Status Survey, 2007.

Notes: For variable definitions, please see the text. All regressions include the following controls: age, age ${ }^{2}$, tenure, tenure ${ }^{2}$, education, industry, occupation, firm size, location, hourly wage, annual hours worked, and intention to quit. Standard errors in parentheses.

***significant at the 1 percent level; ${ }^{* *}$ significant at the 5 percent level; *significant at the 10 percent level. 
Table 10 Probit Estimates on the marginal effects on the incidence of company-sponsored training of being on fixed-term contracts and being not on the standard employment track in 2007: female employees

\begin{tabular}{c|c}
\hline Dependent variables & $\begin{array}{c}\text { Prob (participation in } \\
\text { company-sponsored training } \\
\text { and development program) }\end{array}$ \\
\hline fixedterm & 0.002 \\
\hline nonstandard & $(0.005)$ \\
\hline Observations & $-0.058 * * *$ \\
Pseudo R-squared & $(0.004)$ \\
Obs. Probability & 131302 \\
Predicted Probability & 0.187 \\
\hline
\end{tabular}

Source: the Employment Status Survey, 2007.

Notes: For variable definitions, please see the text. All regressions include the following controls: age, age ${ }^{2}$, tenure, tenure ${ }^{2}$, education, industry, occupation, firm size, location, hourly wage, annual hours worked, and intention to quit. Standard errors in parentheses.

$* * *$ significant at the 1 percent level; **significant at the 5 percent level; *significant at the 10 percent level. 
Table 11 OLS Estimates on the effects on log of hourly earnings of being a nonstandard employee on an indefinite contract vs. being self-employed over 1982-2007: women

\begin{tabular}{|c|c|c|c|c|c|}
\hline & $\begin{array}{c}(1) \\
1982\end{array}$ & $\begin{array}{c}(2) \\
1987\end{array}$ & $\begin{array}{c}(3) \\
1992\end{array}$ & $\begin{array}{c}(4) \\
2002\end{array}$ & $\begin{array}{c}(5) \\
2007\end{array}$ \\
\hline dependent variable & \multicolumn{5}{|c|}{ ln(hourly earnings) } \\
\hline nonstandard and fixed-term & $\begin{array}{c}-0.184^{* * *} \\
(0.008)\end{array}$ & $\begin{array}{c}-0.168 * * * \\
(0.006)\end{array}$ & $\begin{array}{c}-0.240 * * * \\
(0.005)\end{array}$ & $\begin{array}{c}-0.217 * * * \\
(0.005)\end{array}$ & $\begin{array}{c}-0.186 * * * \\
(0.004)\end{array}$ \\
\hline nonstandard and indefinite & $\begin{array}{c}-0.202 * * * \\
(0.007)\end{array}$ & $\begin{array}{c}-0.165^{* * *} \\
(0.006)\end{array}$ & $\begin{array}{c}-0.244^{* * *} \\
(0.006)\end{array}$ & $\begin{array}{c}-0.232 * * * \\
(0.005)\end{array}$ & $\begin{array}{c}-0.196 * * * \\
(0.006)\end{array}$ \\
\hline standard and fixed-term & $\begin{array}{c}-0.102^{* * *} \\
(0.019)\end{array}$ & $\begin{array}{c}-0.130 * * * \\
(0.023)\end{array}$ & $\begin{array}{c}-0.103^{* * *} \\
(0.019)\end{array}$ & $\begin{array}{c}-0.231 * * * \\
(0.025)\end{array}$ & $\begin{array}{c}-0.262 * * * \\
(0.029)\end{array}$ \\
\hline self-employed & $\begin{array}{c}-0.299 * * * \\
(0.007)\end{array}$ & $\begin{array}{c}-0.270 * * * \\
(0.007)\end{array}$ & $\begin{array}{c}-0.188 * * * \\
(0.006)\end{array}$ & $\begin{array}{c}-0.272 * * * \\
(0.007)\end{array}$ & $\begin{array}{c}-0.429 * * * \\
(0.007)\end{array}$ \\
\hline $\begin{array}{r}\text { \# of obs } \\
\text { ajdusted R-sq }\end{array}$ & $\begin{array}{c}131672 \\
0.447\end{array}$ & $\begin{array}{l}134009 \\
0.4301\end{array}$ & $\begin{array}{l}178286 \\
0.4193\end{array}$ & $\begin{array}{l}149678 \\
0.4153\end{array}$ & $\begin{array}{c}149918 \\
0.407\end{array}$ \\
\hline
\end{tabular}

Source: the Employment Status Survey, 1982, 1987, 1992, 1997, 2002, and 2007.

Notes: For variable definitions, please see the text. All regressions include the following controls: age, age ${ }^{2}$, tenure, tenure ${ }^{2}$, education, industry, occupation, firm size, and location. Standard errors in parentheses.

***significant at the 1 percent level; **significant at the 5 percent level; *significant at the 10 percent level. 
Table 12 Annual Transition Matrix of Women

\begin{tabular}{|c|c|c|c|c|c|c|}
\hline & & \multicolumn{5}{|c|}{ current status } \\
\hline & & $\begin{array}{c}\text { indefinite } \\
\text { contract }\end{array}$ & fixed contract & self-employed & Non-employment & total \\
\hline \multirow{5}{*}{ 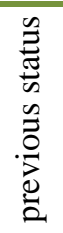 } & indefinite contract & 37.03 & 0.33 & 0.17 & 2.79 & 40.31 \\
\hline & fixed contract & 0.23 & 4.56 & 0.03 & 1.04 & 5.87 \\
\hline & self-employed & 0.09 & 0.04 & 14.48 & 0.49 & 15.10 \\
\hline & Non-employment & 2.64 & 1.32 & 0.48 & 34.28 & 38.72 \\
\hline & total & 40.00 & 6.24 & 15.16 & 38.60 & 100.00 \\
\hline
\end{tabular}

Source: the Employment Status Survey, 1982, 1987, 1992, 1997, 2002, and 2007. 
Figure 1 Size of the Secondary Segment of the Japanese Labor Market as a Percentage of Total Employment over the last 25 years: Using two alternative definitions

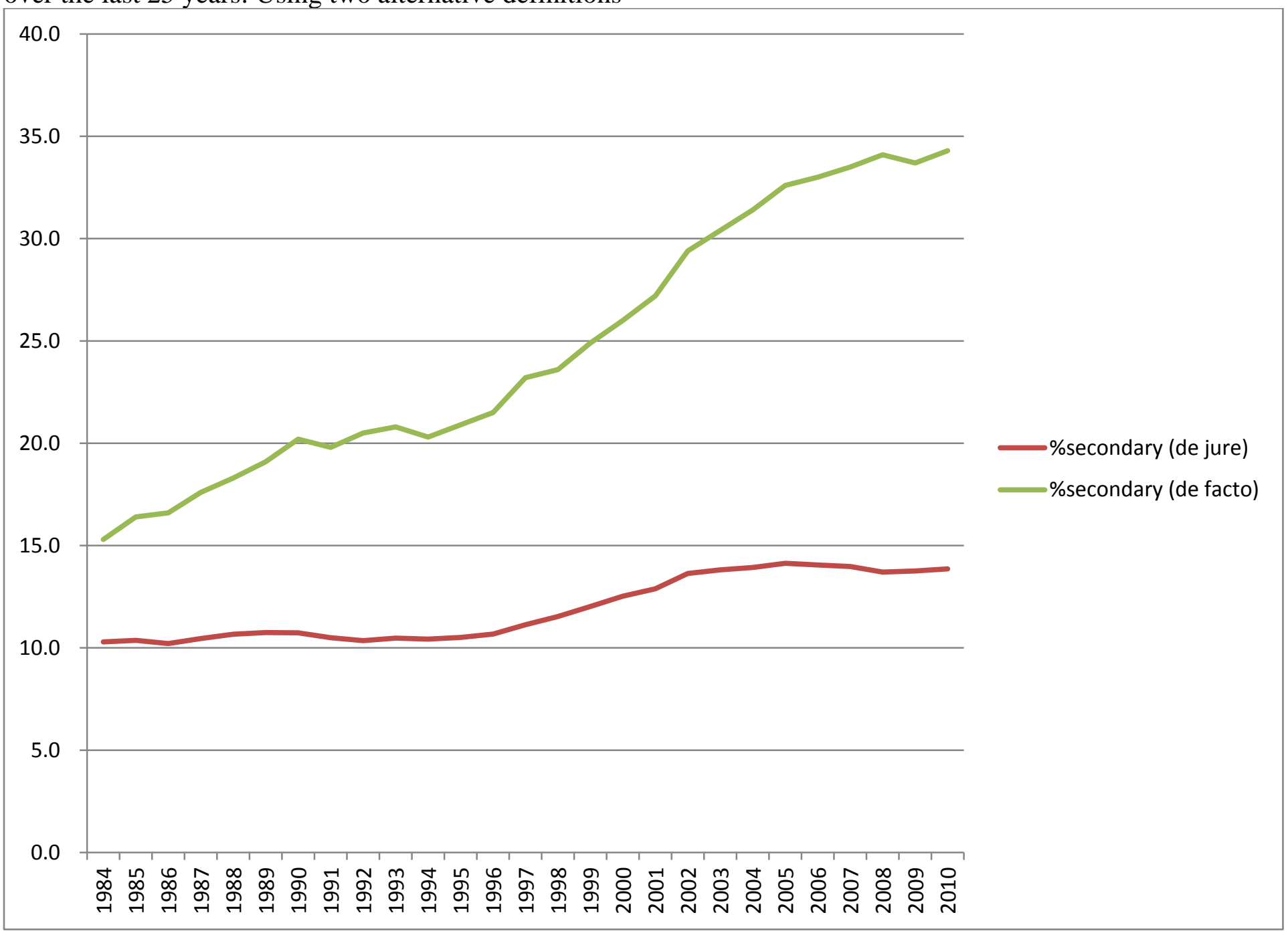

Source: the Labor Force Survey. The data on the proportion of the secondary segment employment using the de jure definition are from Basic Tabulation Historical Data 4. The data on the proportion of the secondary segment employment using the de facto definition are from Detailed Tabulation Historical Data 9. 
Figure 2 Different categories of workers as percentages of the population aged 18-70 in Japan: 1982-2007

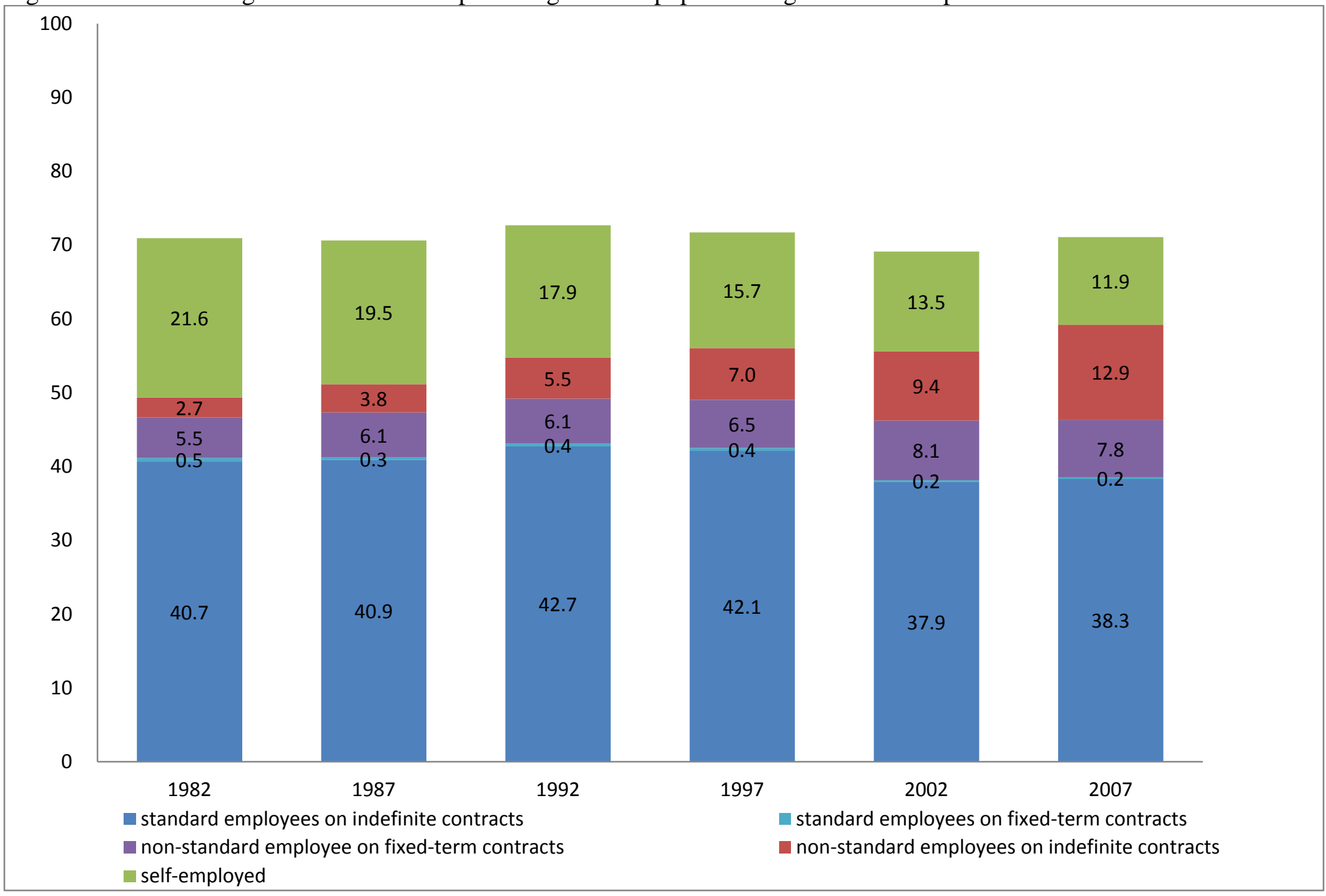

Source: the Employment Status Survey, 1982, 1987, 1992, 1997, 2002, and 2007. 
Figure 3 Different categories of workers as percentages of the population aged 18-70 in Japan: 1982-2007 and male

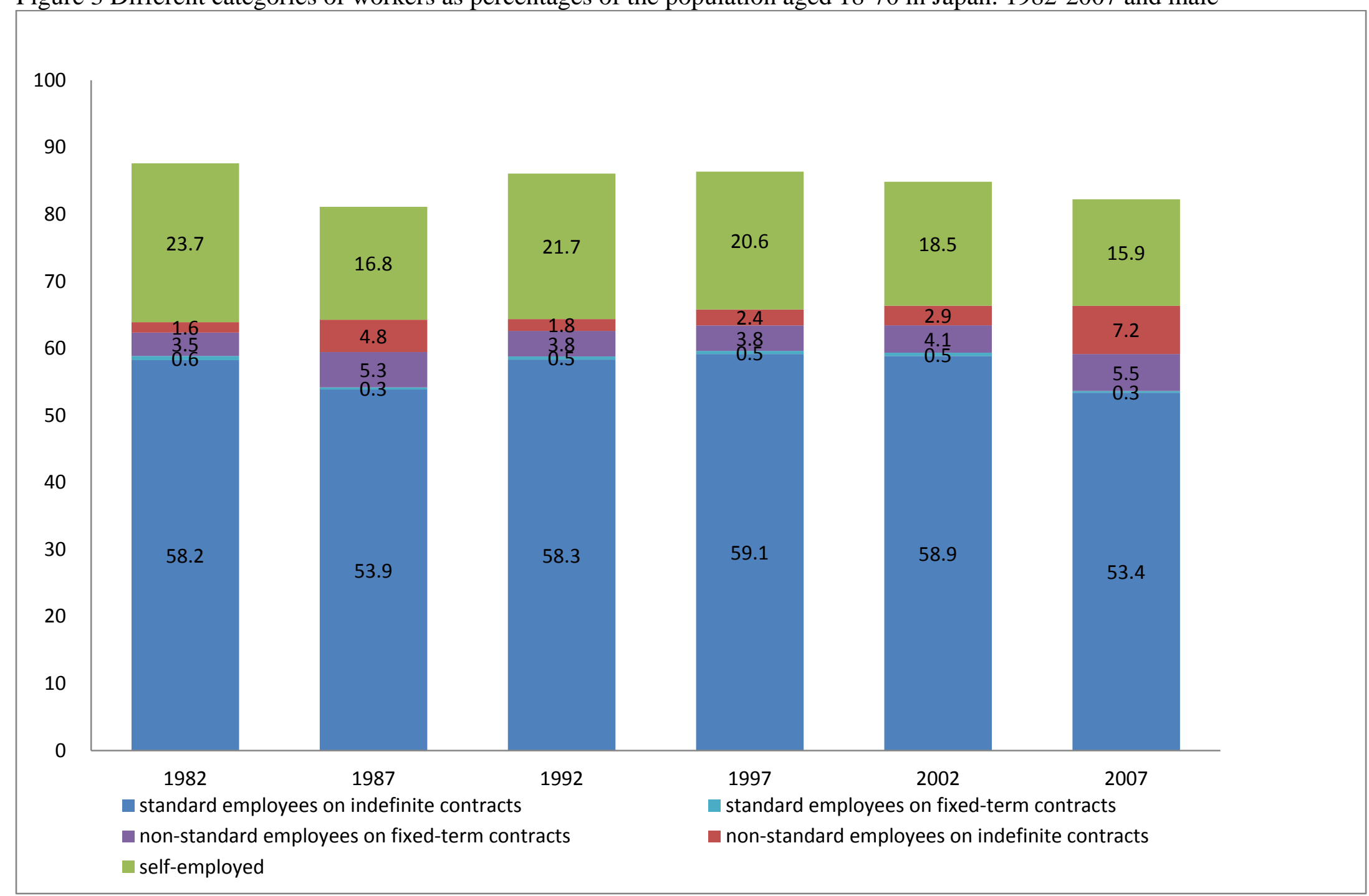

Source: the Employment Status Survey, 1982, 1987, 1992, 1997, 2002, and 2007. 
Figure 4 Different categories of workers as percentages of the population aged 18-70 in Japan: 1982-2007 and female

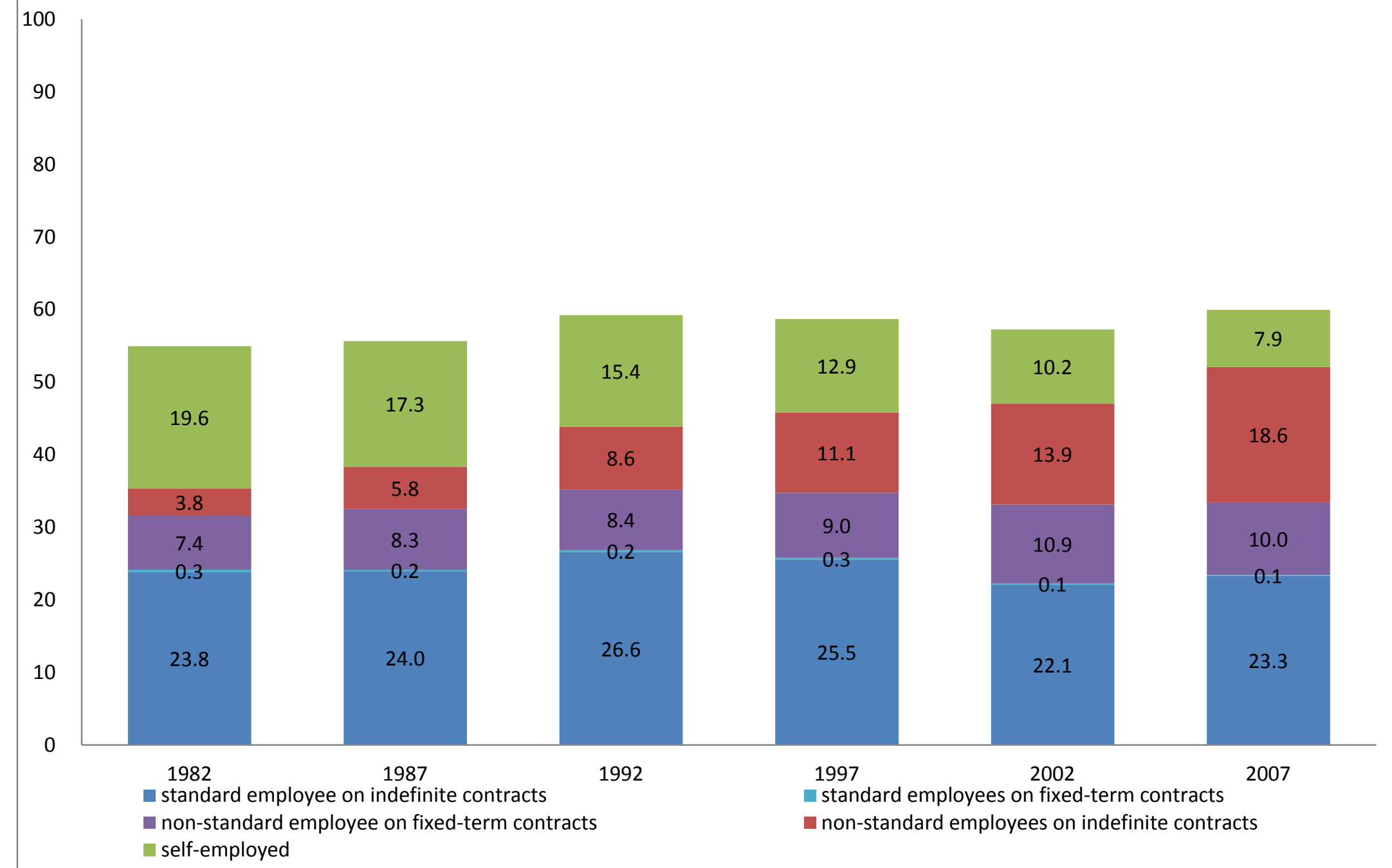

Source: the Employment Status Survey, 1982, 1987, 1992, 1997, 2002, and 2007. 
Figure 5 Scatter Diagram with $\Delta \%$ Nonstandard Employment with Indefinite Contracts over 1982-2002 and $\Delta \%$ Self-employment over 1982-2002 for Different Industries

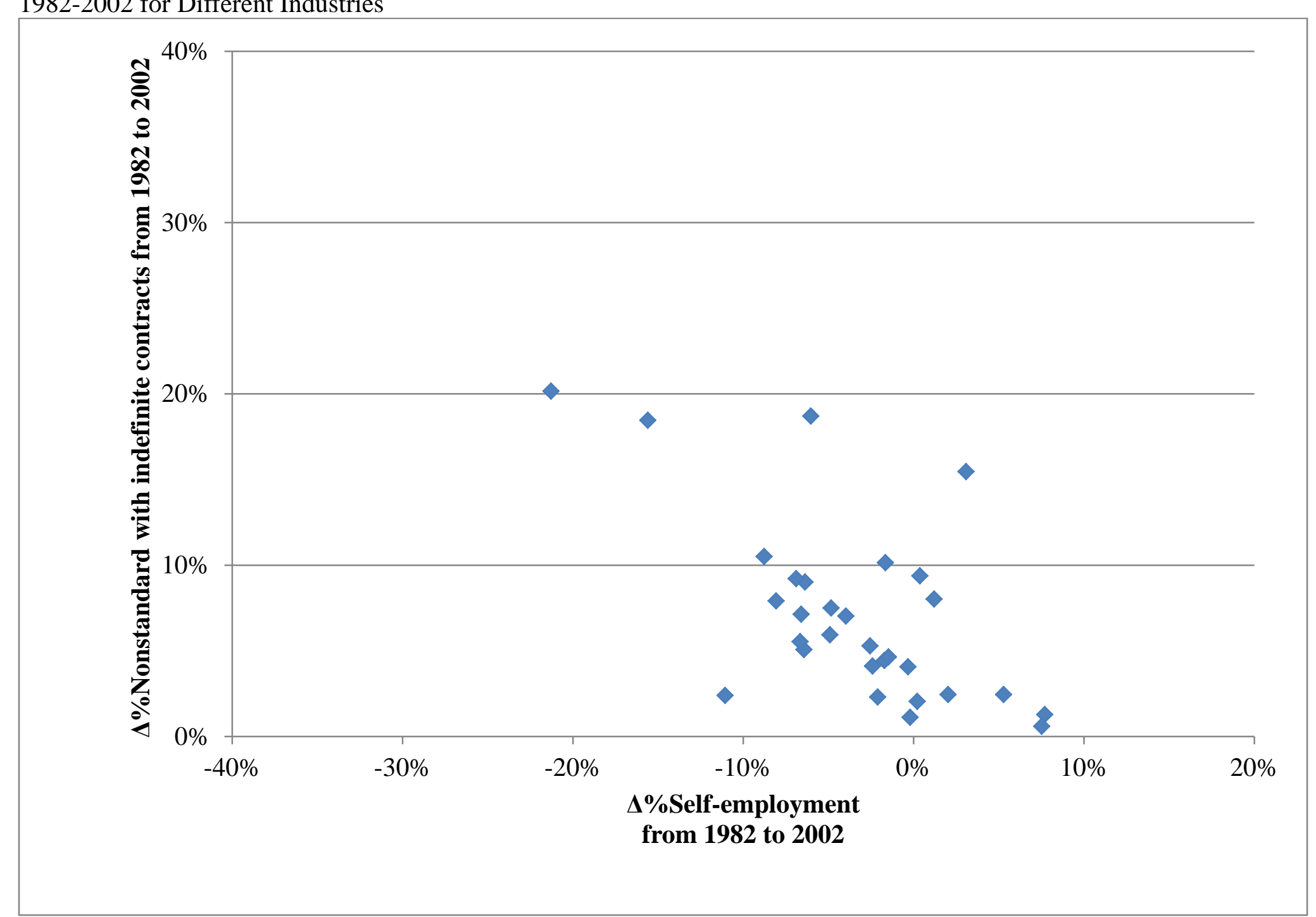

Source: the Employment Status Survey, 1982 and 2007. 
Figure 6 Different categories of workers as percentages of the population aged 22-30 in Japan: 1982-2007

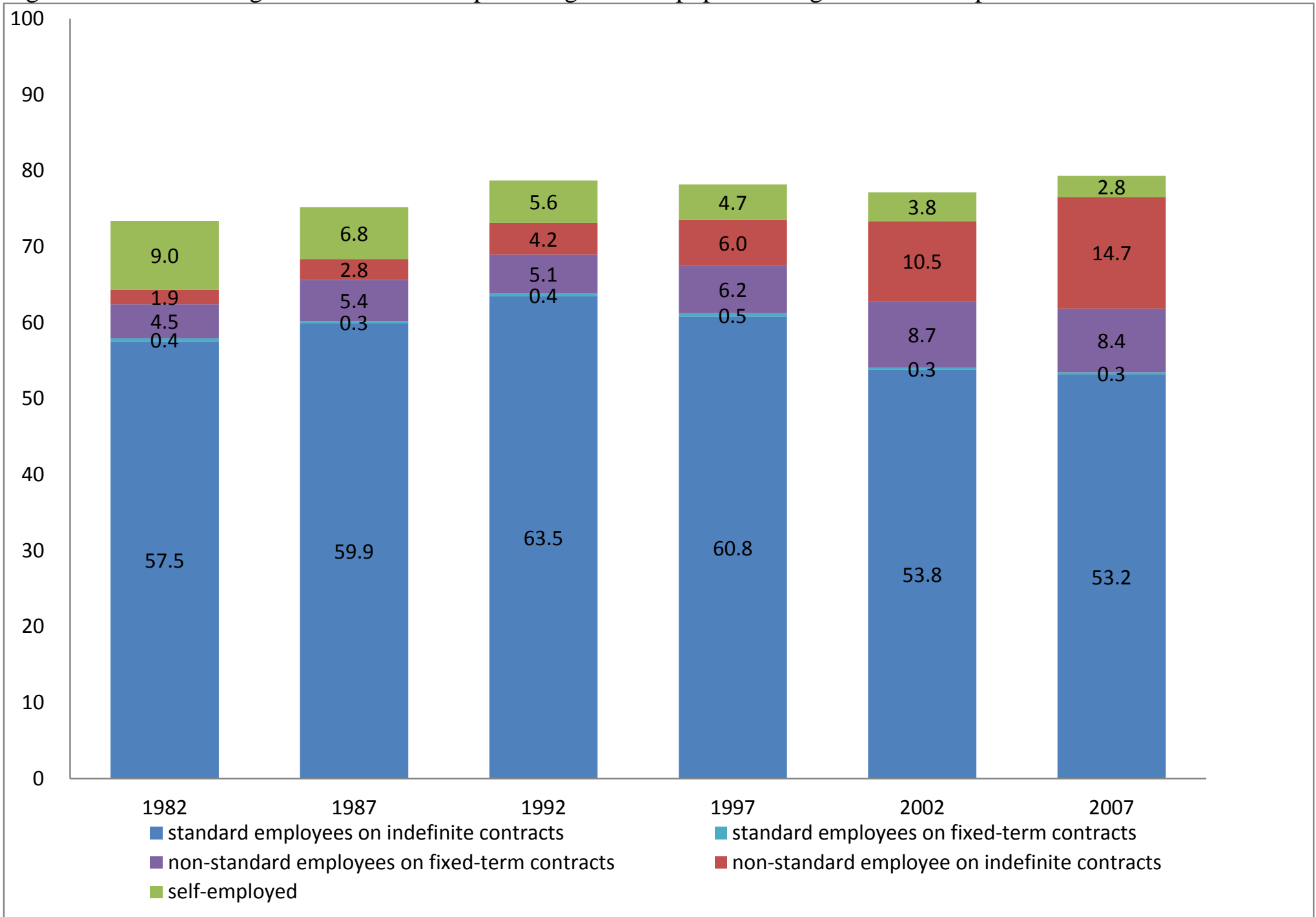

Source: the Employment Status Survey, 1982, 1987, 1992, 1997, 2002, and 2007. 
Figure 7 Different categories of workers as percentages of the population aged 22-30 in Japan: 1982-2007 and male

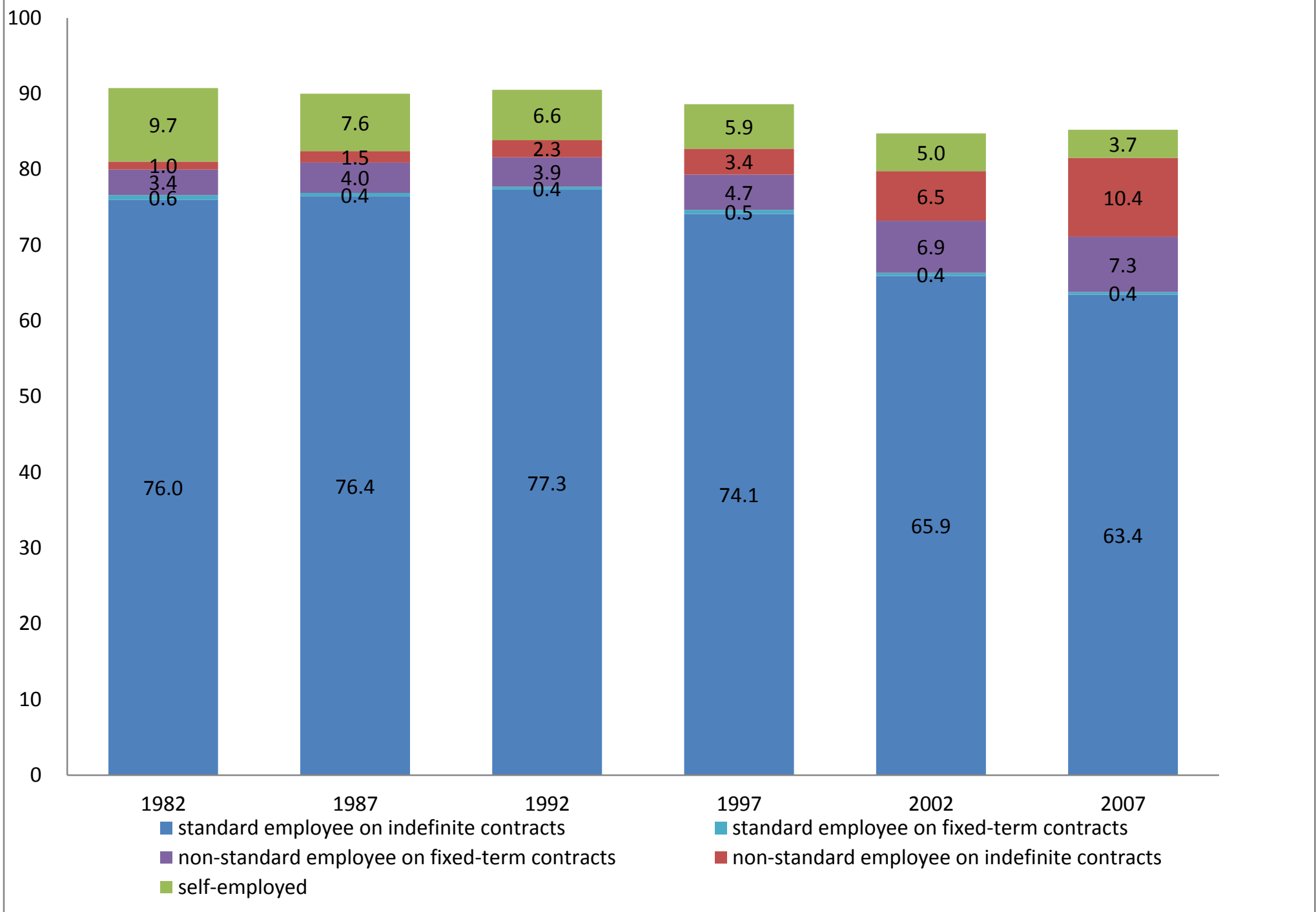

Source: the Employment Status Survey, 1982, 1987, 1992, 1997, 2002, and 2007. 
Figure 8 Different categories of workers as percentages of the population aged 22-30 in Japan: 1982-2007 and female

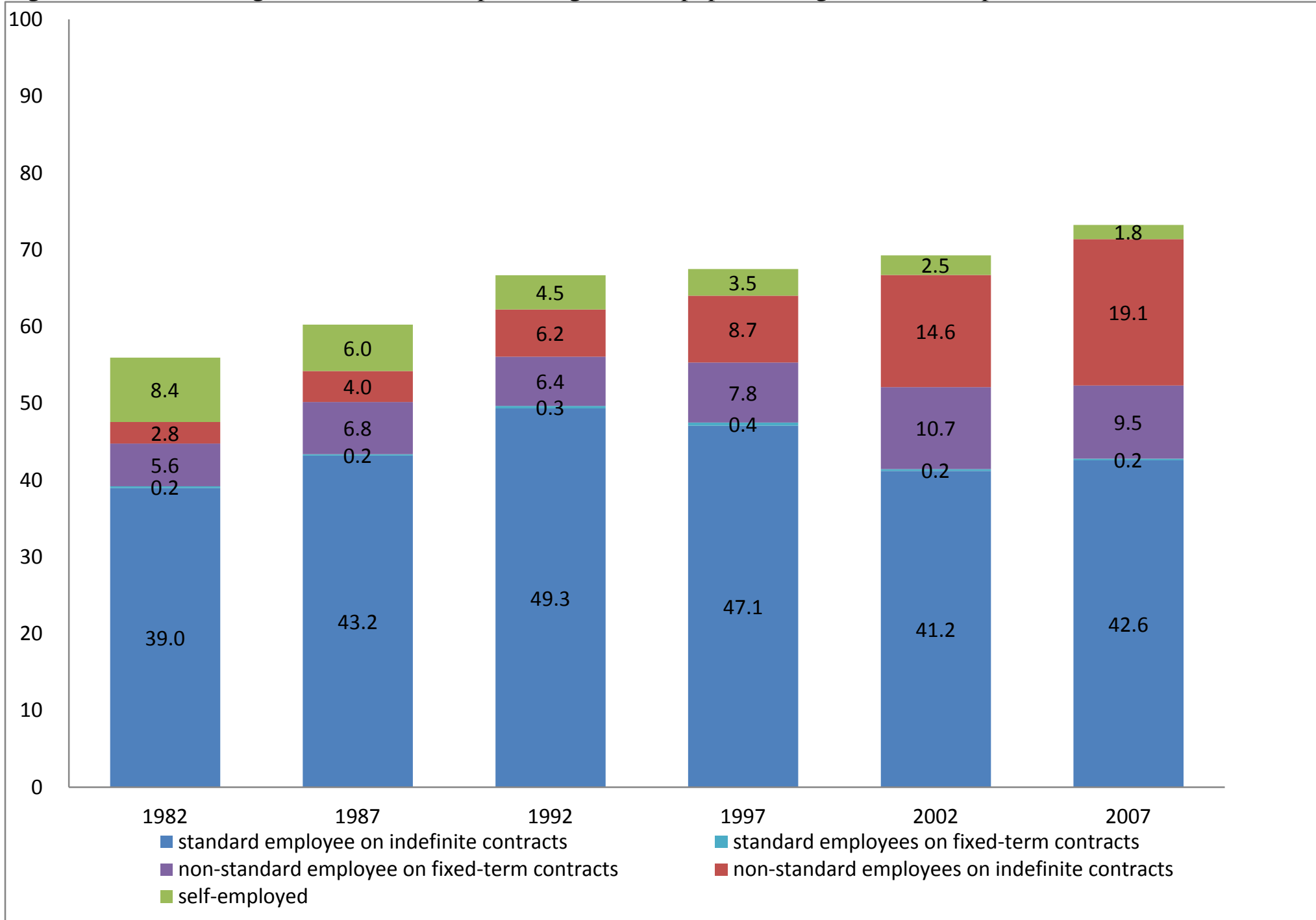

Source: the Employment Status Survey, 1982, 1987, 1992, 1997, 2002, and 2007. 